\title{
Microencapsulation Quality and Efficiency of Lactobacillus casei by Spray Drying Using Maltodextrin and Vegetable Extracts
}

\author{
Paola Hernández-Carranza ${ }^{1}$, Aurelio López-Malo ${ }^{1} \&$ María-Teresa Jiménez-Munguía ${ }^{1}$ \\ ${ }^{1}$ Department of Chemical, Food and Environmental Engineering, Universidad de las Américas Puebla, Mexico \\ Correspondence: María-Teresa Jiménez-Munguía, Department of Chemical, Food and Environmental \\ Engineering, Universidad de las Américas Puebla, Mexico. E-mail: mariat.jimenez@udlap.mx
}

Received: November 17, 2013 Accepted: December 13, 2013 Online Published: December 24, 2013

doi:10.5539/jfr.v3n1p61

URL: http://dx.doi.org/10.5539/jfr.v3n1p61

\begin{abstract}
Survival and quality efficiency of Lactobacillus casei microencapsulated by spray drying using different vegetable extracts (asparagus, artichoke, orange or grapefruit peel) were evaluated. Aqueous suspensions of the vegetable extracts with or without maltodextrin (adjusting to $25 \% \mathrm{w} / \mathrm{w}$ ) were prepared for the microencapsulation of $L$. casei. The evaluated spray drying conditions were at a fixed air inlet temperature (Tin) of $145{ }^{\circ} \mathrm{C}$ and varying the aqueous suspensions flux (Q) of 10 or $15 \mathrm{~g} / \mathrm{min}$. Survival of $L$. casei was evaluated after the spray drying process and after 60 days of storage at $25{ }^{\circ} \mathrm{C}$. The quality efficiency of the microencapsulated $L$. casei was evaluated by measuring in the product, physicochemical properties (moisture content, $\mathrm{a}_{\mathrm{w}}$ ), determining moisture gain and modeling adsorption isotherms, besides analyzing micrographs. Results demonstrated that moisture content of the different spray drying powders was less than $2 \% \mathrm{wb}$ and less than 0.30 of $\mathrm{a}_{\mathrm{w}}$. It was evidently that the use of maltodextrin reduced $50 \%$ the powders moisture gain (hygroscopicity) therefore reducing stickiness problems during storage. The Scanning Electron Microscopy (SEM) confirmed individual particles formation with a homogeneous coat when using vegetable extracts + maltodextrin and hence better powder quality than without it. The microbial reduction of $L$. casei after the spray drying process was of one log cycle and significantly different $(p<0.05)$ with the presence of maltodextrin when using orange or grapefruit peel. A microbial population over $10^{7} \mathrm{cfu} / \mathrm{g}$ of $L$. casei microencapsulated was maintained after 60 days of storage which guarantees its use to develop functional food.
\end{abstract}

Keywords: microencapsulation, Lactobacillus, spray drying, vegetable extracts

\section{Introduction}

The encapsulation processes have been widely used in the chemical, pharmaceutical and food industry in aim to protect an active compound from environmental conditions (oxygen, water, acid, interactions with other ingredients), which may affect its stability during processing, to impart controlled release or to change its physical properties, reducing stickiness during storage or transportation (Boonyai, Bhandhari, \& Howes, 2004; Palzer, 2005; Fuchs et al., 2006; Werner, Jones, Paterson, Archer, \& Pearce, 2007). The product obtained from the different encapsulation technologies can be classified according to the final product size; they are called capsules or macrocapsules when these are bigger than $5,000 \mu \mathrm{m}$, microcapsules when the size is between 0.1 and $5,000 \mu \mathrm{m}$ and nanocapsules when these are smaller than $0.1 \mu \mathrm{m}$ (Baker, 1987; Murugesan \& Orsat, 2012).

Among the microencapsulation processes, the spray drying process has been proven to be a cost-effective one-step process, in comparison with other techniques (fluidized bed - Wüster tube, liophylization, emulsification, or extrusion) (Anal \& Singh, 2007; Murugesan \& Orsat, 2012; Amin, Thakur, \& Jain, 2013). The encapsulation of different bioactive compounds as antioxidants, vitamins, minerals, fatty acids, including probiotics, by the spray drying process, has been studied intensively in recent years to optimize the process parameters, like the air drying temperature and flux, the spraying solution or suspension composition, concentration and flux which may confer specific properties to the microcapsules depending on its application (Masters, 1985; Fuchs et al., 2006; Gianfrancesco, Turchiuli, Flick, \& Dumoulin, 2010; Tan, Ibrahim, Kamil, \& Taip, 2011).

In several studies, concerning probiotic microencapsulation by spray drying, the thermal resistance of some lactobacilli or bifidobacteria has been evaluated due to the cell damage caused during the process (Ananta, Volkert, \& Knorr, 2005; Desmond, Stanton, Fitzgerald, Collins, \& Ross, 2001; Gardiner et al., 2000). In 
particular, probiotic microencapsulation advances has also been focused in evaluating different coating materials to enhance the viability of probiotics during processing of food, storage until its consumption and passage through the gastrointestinal tract, and arrive to the colon at an adequate microbial population concentration $\left(10^{6}-10^{7} \mathrm{cfu} / \mathrm{g}\right)$ (Rokka \& Rantamäki, 2010; FAO/WHO, 2006). The polysaccharides that have been used for probiotic microencapsulation by spray drying are soluble starch, maltodextrins, polydextroses, cellulose, pectin, alginate, carrageenan, acacia gum, or xanthan gum; and among proteins, gelatin, whey protein isolate or skim milk (Anal \& Singh, 2007; Rokka \& Rantamäki, 2010; Nazzaro, Orlando, Fratianni, \& Coppola, 2012). Some other materials have been suggested to be used in mixture with the coating agents like some non-digestible carbohydrates, such as galacto-oligosaccharides or fructooligosaccharides, which may play a role as prebiotics in the colon (Corcoran, Ross, Fitzgerald, \& Stanton, 2004; Gibson, Probert, Loo, Rastall, \& Roberfroid, 2004). Some fruits and vegetables rich in these kind of compounds are tubers, quince, celery, arthichoke, broccoli, carrots, banana, plum, oranges, and apples, among others (Chau \& Huang, 2003; Altieri, Bevilacqua, \& Sinigaglia, 2011). However, special attention must be given in choosing the mixture suspension to be used for microencapsulation by spray drying due to some stickiness problems in the drying chamber (Palzer, 2005; Gianfrancesco, Turchiuli, Flick, \& Dumoulin, 2010) or during storage (Langrish \& Chiou, 2008) which may affect the final product quality or spray drying efficiency.

Therefore, the aim of the present study was to evaluate different vegetable extracts (artichoke, green asparagus, orange peel and grapefruit peel) to be used sole or in mixture with maltodextrin in the microencapsulation efficiency and quality of Lactobacillus casei spray dried. Our hypotheses of achieving good quality properties of the microencapsulating probiotic relies in the good characteristics of maltodextrin as coating agent which may compensate the disadvantages that vegetable extracts may present during the spray drying process (stickiness) or during storage (hygroscopicity).

\section{Method}

\subsection{Materials}

Artichoke var. green globe (Cynara scolymus), green asparagus (Asparagus officinalis), orange peel (Citrus sinensis) and grapefruit peel (Citrus paradise), both with albedo, were purchased in a local market of Puebla, Mexico. Maltodextrin 10 DE (Globe 19100, Freskal, Mexico) was used for the microencapsulating process.

\subsection{Vegetable Extracts Dispersions Preparation and Characterization}

\subsubsection{Preparation}

Vegetables and citrus peels were cut into slices of approximately one centimeter thick and dried in a hot air dryer (Food Dehydrator, Model 3500, Excalibur, U.S.A) at $35^{\circ} \mathrm{C}$ for $48 \mathrm{~h}$. Dried samples were milled and sifted passing through a sieve No. $35(500 \mu \mathrm{m})$ (Cole - Parmer, U.S.A), and then packed in glass containers until the extraction process. This latter consisted in mixing, with a magnet stirrer, $10 \mathrm{~g}$ of dried vegetables and $90 \mathrm{~g}$ of hot distilled water $\left(80^{\circ} \mathrm{C}\right)$ for $15 \mathrm{~min}$. Dispersions were filtered using a soft cloth to eliminate suspended particles more than $0.05 \mathrm{~mm}$ of size, obtaining the vegetable extracts.

\subsubsection{Characterization}

Eight different samples were prepared for microencapsulation, sole vegetable extracts (asparagus, arthichoke, orange peel and grapefruit peel) obtained as previously described and vegetable extracts with maltodextrin (asparagus $+\mathrm{MD}$, arthichoke $+\mathrm{MD}$, orange peel $+\mathrm{MD}$ and grapefruit peel $+\mathrm{MD}$ ), completing to $25 \%$ of solids $\mathrm{w} / \mathrm{w}$, previously determining total solids content in the vegetable extracts by $16.032 \mathrm{AOAC}$ method (2000). Density was obtained by 963.37 AOAC method (2000) and dynamic viscosity was determined using a Cannon-Fenske viscometer (Mod. 350152 I, Cannon Instrument, Co, U.S.A.).

\subsection{Bacterial Preparation}

The probiotic Lactobacillus casei NRRL (B-1922) was donated by the Agriculture Research Services Department of the United States Department of Agriculture (USDA). L. casei was cultivated in Man, Rogosa \& Sharpe (MRS) broth and agar (Becton Dickinson, Mexico), anaerobically at $35-37{ }^{\circ} \mathrm{C}$. The biomass pellet of $L$. casei was obtained inoculating the probiotic in MRS broth, and after $48 \mathrm{~h}$ of incubation under anaerobiosis at $35-37^{\circ} \mathrm{C}$, it was centrifuged at $12000 \mathrm{rpm}$ for $15 \mathrm{~min}$, maintaining the temperature at $5{ }^{\circ} \mathrm{C}$, to finally obtain the pellet.

\subsection{Microencapsulation Process}

The vegetable extracts dispersions with or without maltodextrin were inoculated, under sterile conditions, with the $L$. casei pellet, obtaining an initial bacterial count of $\approx 10^{11} \mathrm{cfu} / \mathrm{g}$ dispersion. The drying process was done in 
a laboratory scale spray dryer (Mini Spray Dryer, B-290, Büchi Laboertechnik, Switzerland), at a fixed inlet air temperature of $145^{\circ} \mathrm{C}$ and flow dry air of $38 \mathrm{~m}^{3} / \mathrm{h}$. The bi-fluid nozzle used was of $1.5 \mathrm{~mm}$ aperture, passing compressed air at $444 \mathrm{~m}^{3} / \mathrm{h}$, and varying the dispersion flux (Q) to $10 \mathrm{~g} / \mathrm{min}$ or $15 \mathrm{~g} / \mathrm{min}$. The powder recovered was stored in sterile tubes at $25^{\circ} \mathrm{C}$.

\subsection{Bacterial Count}

The efficiency of the microencapsulation process was calculated with the viable bacterial cells before (Ni) and after (Nf) the spray drying process. Bacterial cells count was also measured after 60 days of storage (Ns) at $25{ }^{\circ} \mathrm{C}$. Samples were dispersed in sterile solutions of peptone water, preparing the serial decimal dilutions needed to determine bacterial enumeration (30-300 cfu/g) in MRS agar, using an automatic spiral autoplate (Spiral Biotech Autoplate 4000, Advanced Instruments Inc., USA). Plates were incubated at $35-37{ }^{\circ} \mathrm{C}$ under anaerobiosis and after 48h, counting was done with a scanner (Spiral Biotech Q-count, Advanced Instruments Inc., USA).

\subsection{Physical and Physcochemical Characterization of Powders}

2.6.1 Moisture content and $\mathrm{a}_{\mathrm{w}}$ determinations

Moisture content in powders was determined by 925.25 method of AOAC (2000), drying in a vacuum oven at $70{ }^{\circ} \mathrm{C}$, while water activity $\left(\mathrm{a}_{\mathrm{w}}\right)$ was measured with a hygrometer (AquaLab 3TE, Decagon Devices Inc., USA) at $25^{\circ} \mathrm{C}$.

\subsubsection{Moisture Gain (Hygroscopicity) Test}

$1 \mathrm{~g}$ of powder sample was measured in weight glass bottles and these were placed in a desiccator with $\mathrm{NaCl}$ saturated solution to provide a relative humidity of $75 \%$. Every three days, the powder weight was registered during 15 days. The weight gained of the powder was attributed to absorbed moisture by the powder and therefore relate it to the hygroscopicity property of the powder, expressed in $\mathrm{g}_{2} \mathrm{O} / \mathrm{g} \mathrm{db}$.

\subsubsection{Adsorption Isotherm Determination and Modelling}

The methodology of Palou, López-Malo and Argaiz (1997) was used to determine the adsorption isotherm of all powders using the followed saturated solutions at $25^{\circ} \mathrm{C}: \mathrm{LiCl}\left(\mathrm{a}_{\mathrm{w}} 0.12\right), \mathrm{MgCl}_{2}\left(\mathrm{a}_{\mathrm{w}} 0.34\right), \mathrm{NaBr}\left(\mathrm{a}_{\mathrm{w}} 0.60\right), \mathrm{NaCl}$ $\left(\mathrm{a}_{\mathrm{w}} 0.75\right), \mathrm{KCl}\left(\mathrm{a}_{\mathrm{w}} 0.85\right)$ and $\mathrm{BaCl}_{2}\left(\mathrm{a}_{\mathrm{w}} 0.90\right)$. The model used to describe the isotherms was GAB (Equation 1), where $\mathrm{M}\left(\mathrm{g} \mathrm{H}_{2} \mathrm{O} / \mathrm{g} \mathrm{db}\right)$ is the moisture content in equilibrium at an adjusted $\mathrm{a}_{\mathrm{w}}, \mathrm{C}$ and $\mathrm{K}$ are model constants while $\mathrm{Mo}\left(\mathrm{g} \mathrm{H}_{2} \mathrm{O} / \mathrm{g} \mathrm{db}\right)$ is the monolayer moisture content of the powder.

$$
M=\frac{M o C K a_{w}}{\left(1-K a_{w}\right)\left(1-K a_{w}+C K a_{w}\right)}
$$

\subsubsection{Micrographs}

L. casei microencapsulated with artichoke or artichoke+MD were selected to analyze the powder structure by scanning electron microscopy (SEM), using a microscope VEGA LSU (Tescan, Brno, Czech Republic) with an accelerating voltage of $20 \mathrm{kV}$. Samples were placed on a double-tape of copper and conductive carbon which was then fixed on an aluminium support of the microscope. Different micrographs were analyzed using different magnifications of each sample.

\subsection{Statistical Analysis}

All determinations and measures were obtained by triplicate, ANOVA and pair Tukey test were done with $\alpha=0.050$, using the software Minitab v.16 (Lead Technologies Inc., USA).

\section{Results}

\subsection{Spray Drying Process}

The vegetable extracts dispersions, with or without maltodextrin were characterized (Table 1), determining the total solid content, density and viscosity. The total solid content ranged from 4.38 to $7.05 \%$, presenting a significant difference $(\mathrm{p}<0.05)$ among these, being the artichoke, the vegetable with the least value. The vegetable extract dispersions with maltodextrin affected the density and viscosity $(p<0.05)$. The dispersion density was considered to calibrate the spray drying pump and adjust the liquid flux to $10 \mathrm{~g} / \mathrm{min}$ or $15 \mathrm{~g} / \mathrm{min}$.

The outlet air temperature (Tout) was monitored during the drying process, the average of the Tout with a dispersion flux (Q) of $10 \mathrm{~g} / \mathrm{min}$, was $80 \pm 4^{\circ} \mathrm{C}$, while with a $\mathrm{Q}$ of $15 \mathrm{~g} / \mathrm{min}$, the Tout was $68 \pm 4{ }^{\circ} \mathrm{C}$, presenting a significant difference $(\mathrm{p}<0.05)$ for the different $\mathrm{Q}$ values. 
Table 1. Total solids content, density ${ }^{1}$ and viscosity ${ }^{1}$ of dispersions with and without maltodextrin (MD)

\begin{tabular}{llll}
\hline $\begin{array}{l}\text { Suspensions of } \\
\text { vegetable sources }\end{array}$ & $\begin{array}{l}\text { \% Total } \\
\text { solids }\end{array}$ & $\begin{array}{l}\text { Density } \\
\mathrm{kg} / \mathrm{m}^{\mathrm{s}}\end{array}$ & $\begin{array}{l}\text { Viscosity } \\
\mathrm{mPa}^{*} \mathrm{~s}\end{array}$ \\
\hline Orange peel & $5.25 \pm 0.06^{\mathrm{a}}$ & $993 \pm 0.01^{\mathrm{a}}$ & $1.75 \pm 0.09^{\mathrm{a}}$ \\
Grapefruit peel & $7.05 \pm 0.09^{\mathrm{b}}$ & $987 \pm 0.01^{\mathrm{a}}$ & $1.79 \pm 0.03^{\mathrm{a}}$ \\
Asparagus & $6.24 \pm 0.21^{\mathrm{c}}$ & $984 \pm 0.01^{\mathrm{a}}$ & $1.45 \pm 0.08^{\mathrm{a}}$ \\
Artichoke & $4.38 \pm 0.33^{\mathrm{a}}$ & $982 \pm 0.00^{\mathrm{a}}$ & $1.34 \pm 0.08^{\mathrm{a}}$ \\
Orange peel + MD & $25.00 \pm 0.00^{\mathrm{e}}$ & $897 \pm 0.00^{\mathrm{b}}$ & $8.39 \pm 0.16^{\mathrm{b}}$ \\
Grapefruit peel + MD & $25.00 \pm 0.00^{\mathrm{e}}$ & $895 \pm 0.00^{\mathrm{b}}$ & $15.20 \pm 0.39^{\mathrm{c}}$ \\
Asparagus + MD & $25.00 \pm 0.00^{\mathrm{e}}$ & $890 \pm 0.00^{\mathrm{b}}$ & $6.61 \pm 0.14^{\mathrm{a}}$ \\
Artichoke + MD & $25.00 \pm 0.00^{\mathrm{e}}$ & $901 \pm 0.00^{\mathrm{c}}$ & $5.76 \pm 0.06^{\mathrm{e}}$ \\
\hline
\end{tabular}

${ }^{1}$ Measurements at $20^{\circ} \mathrm{C}$.

${ }^{\mathbf{a}, \mathbf{b}, \mathbf{c}, \mathbf{d}, \mathbf{e}}$ Superscripts with different letters indicate statistical differences $(\mathrm{p}<0.05)$.

\subsection{Phsysicochemical Properties of the Encapsulated Probiotic}

The encapsulation of $L$. casei was done with a Tin of $145{ }^{\circ} \mathrm{C}$ and two different suspension flux Q of 10 or 15 $\mathrm{g} / \mathrm{min}$ (Table 2). Due to the low total solids content and chemical composition, the suspensions prepared with asparagus and artichoke at the higher Q of $15 \mathrm{~g} / \mathrm{min}$, wet quenching was presented in the spray dryer chamber and no powder was obtained. It is demonstrated that moisture content of the encapsulated probiotic is in a range of 1.44 to $1.94 \mathrm{~g} / 100 \mathrm{~g}$ wb with no significant differences among the different suspensions used for encapsulation nor did the water activity which is in a range of 0.20 to 0.35 .

Table 2. Moisture content and water activity of $L$. casei microencapsulated with different vegetable extracts with or without maltodextrin (MD), at $145^{\circ} \mathrm{C}$ and different suspension flux (Q)

\begin{tabular}{llll}
\hline $\begin{array}{l}\text { Suspensions for } \\
\text { microencapsulation }\end{array}$ & $\begin{array}{l}\mathrm{Q} \\
\mathrm{g} / \mathrm{min}\end{array}$ & $\begin{array}{l}\text { Moisture } \\
\mathrm{g} / 100 \mathrm{~g} \mathrm{wb}\end{array}$ & $\mathrm{a}_{\mathrm{w}}$ \\
\hline Orange peel & 10 & $1.56 \pm 0.17^{\mathrm{a}}$ & $0.28 \pm 0.01^{\mathrm{a}}$ \\
Grapefruit peel & & $1.55 \pm 0.39^{\mathrm{a}}$ & $0.20 \pm 0.01^{\mathrm{a}}$ \\
Asparagus & & $1.59 \pm 0.05^{\mathrm{a}}$ & $0.31 \pm 0.05^{\mathrm{a}}$ \\
Artichoke & & $1.83 \pm 0.03^{\mathrm{a}}$ & $0.28 \pm 0.01^{\mathrm{a}}$ \\
Orange peel + MD & 10 & $1.94 \pm 0.05^{\mathrm{a}}$ & $0.29 \pm 0.01^{\mathrm{a}}$ \\
Grapefruit peel + MD & & $1.84 \pm 0.07^{\mathrm{a}}$ & $0.21 \pm 0.01^{\mathrm{a}}$ \\
Asparagus + MD & & $1.72 \pm 0.08^{\mathrm{a}}$ & $0.21 \pm 0.01^{\mathrm{a}}$ \\
Artichoke + MD & & $1.64 \pm 0.03^{\mathrm{a}}$ & $0.25 \pm 0.01^{\mathrm{a}}$ \\
Orange peel & 15 & $1.44 \pm 0.30^{\mathrm{a}}$ & $0.32 \pm 0.01^{\mathrm{a}}$ \\
Grapefruit peel & & $1.44 \pm 0.32^{\mathrm{a}}$ & $0.29 \pm 0.01^{\mathrm{a}}$ \\
Asparagus & & $\mathrm{ND}$ & $\mathrm{ND}$ \\
Artichoke & & $\mathrm{ND}$ & $\mathrm{ND}$ \\
Orange peel + MD & 15 & $1.54 \pm 0.30^{\mathrm{a}}$ & $0.35 \pm 0.01^{\mathrm{a}}$ \\
Grapefruit peel + MD & & $1.72 \pm 0.02^{\mathrm{a}}$ & $0.25 \pm 0.01^{\mathrm{a}}$ \\
Asparagus + MD & & $1.52 \pm 0.15^{\mathrm{a}}$ & $0.34 \pm 0.01^{\mathrm{a}}$ \\
Artichoke + MD & & $1.55 \pm 0.42^{\mathrm{a}}$ & $0.26 \pm 0.01^{\mathrm{a}}$ \\
\hline
\end{tabular}

${ }^{a}$ Superscripts with same letters indicate no statistical differences $(\mathrm{p}>0.05)$.

ND: Not determined due to wet quenching.

The microencapsulated probiotic powder presented different physical characteristics during storage. In Figure 1 it is presented the moisture gain when the different powders are submitted to a relative humidity atmosphere of $75 \%$. When using artichoke or asparagus extracts with or without MD for the probiotic encapsulation at a Q value of $15 \mathrm{~g} / \mathrm{min}$, no powder was obtained due to wet quenching during the process. It is clearly showed that the 
microencapsulated powders with vegetable extracts in combination with MD presented a lower moisture gain, $50 \%$ less. This behavior was confirmed with the adsorption isotherms which are demonstrated in Figure 2 . In Table 3 it is showed that a good fit of the GAB model to the experimental data of the adsorption isotherm was obtained $\left(\mathrm{R}^{2}>0.97\right)$, as well as the GAB parameters and the monolayer values, for the different powders.
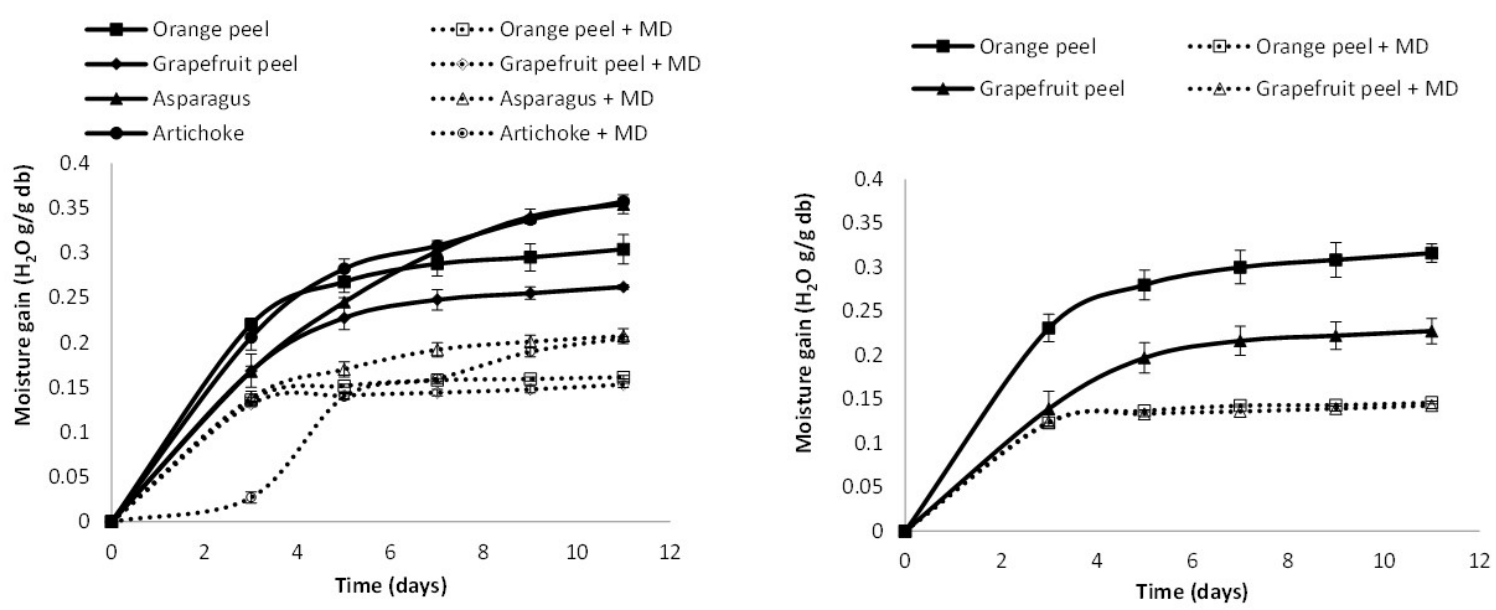

Figure 1. Moisture gain of L. casei microencapsulated with vegetable extracts with or without maltodextrin (MD) by spray drying at $145^{\circ} \mathrm{C}$ of inlet air and suspension flux Q of (a) $10 \mathrm{~g} / \mathrm{min}$ or (b) $15 \mathrm{~g} / \mathrm{min}$ (at this flux, artichoke and asparagus with and without MD presented wet quenching during the process and no powder was obtained)

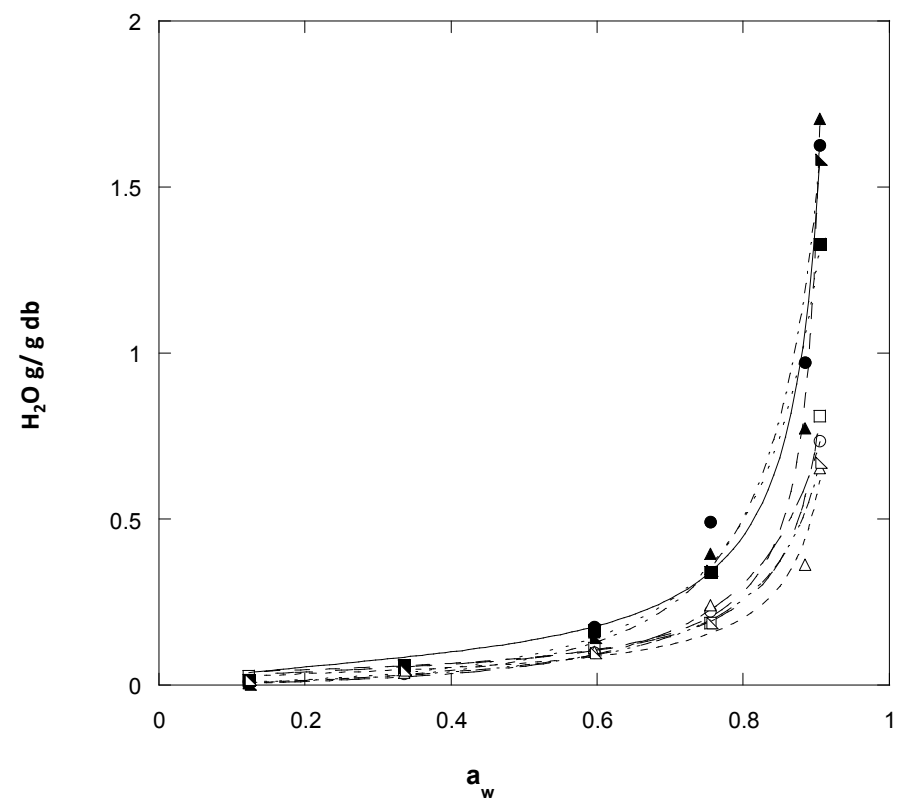

Figure 2. Adsorption isotherms at $25^{\circ} \mathrm{C}$ of $\mathrm{L}$. casei microencapsulated by spray drying with vegetable extracts:

$(\bullet)$ asparagus, $(\mathbf{A})$ artichoke, $(\mathbf{\square})$ orange peel, ( $)$ grapefruit peel without MD and vegetable extracts with MD using same symbols but unfilled, at $145^{\circ} \mathrm{C}$ of inlet air temperature and a flux suspension of $10 \mathrm{~g} / \mathrm{min}$ 
Table 3. Parameters of the GAB model for adsorption isotherms of $L$. casei microencapsulated with different vegetable extracts with or without maltodextrin (MD), at $145^{\circ} \mathrm{C}$ and a spray flux of $10 \mathrm{~g} / \mathrm{min}$

\begin{tabular}{lllll}
\hline Suspensions for microencapsulation & $\mathrm{Mo}\left(\mathrm{H}_{2} \mathrm{O} \mathrm{g} / \mathrm{g} \mathrm{db}\right)$ & $\mathrm{C}$ & $\mathrm{K}$ & $\mathrm{R}^{2}$ \\
\hline Orange peel & 0.21167 & 0.2735 & 0.9834 & 0.9993 \\
Orange peel + MD & 0.04073 & 12.371 & 1.0496 & 0.9998 \\
Grapefruit peel & 0.21823 & 0.2076 & 1.0002 & 0.9998 \\
Grapefruit peel + MD & 0.062 & 0.9101 & 1.0116 & 0.9993 \\
Asparagus & 0.07257 & 5.5669 & 1.0548 & 0.9906 \\
Asparagus + MD & 0.06077 & 1.2822 & 1.0193 & 0.9998 \\
Artichoke & 0.03819 & 69.36 & 1.0799 & 0.9885 \\
Artichoke + MD & 0.03365 & 15.688 & 1.0449 & 0.9734 \\
\hline
\end{tabular}

Some micrographs of the microencapsulated powder were taken to describe the coating formed with artichoke and compare them to the ones that are mixed with MD to analyze the crystallinity of the powder. Similar surface characteristics were obtained with the other vegetable extracts.
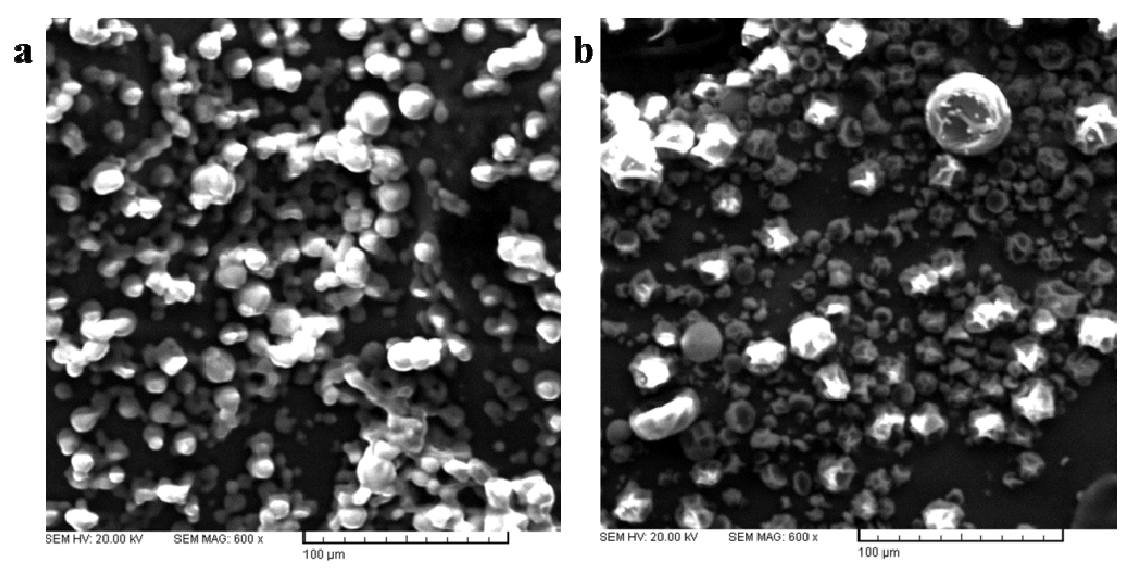

Figure 3. Micrographs of L. casei microencapsulated by spray drying with (a) artichoke extract and (b) artichoke with maltodextrin

\subsection{Probiotic Survival}

Table 4. Microbial reduction of $L$. casei encapsulated with vegetable extracts with or without maltodextrin (MD), after spray drying process and storage at $25^{\circ} \mathrm{C}$

\begin{tabular}{lll}
\hline $\begin{array}{l}\text { Suspensions for } \\
\text { microencapsulation }\end{array}$ & $\begin{array}{l}\text { Microbial reduction after spray drying } \\
\log (\mathrm{Ni} / \mathrm{Nf})\end{array}$ & $\begin{array}{l}\text { Microbial reduction after storage } \\
\log (\mathrm{Nf} / \mathrm{Ns})\end{array}$ \\
\hline Orange peel & $1.25 \pm 0.15^{\mathrm{a}}$ & $4.49 \pm 0.08^{\mathrm{b}}$ \\
Orange peel + MD & $0.71 \pm 0.01^{\mathrm{b}}$ & $3.82 \pm 0.06^{\mathrm{c}}$ \\
Grapefruit peel & $1.18 \pm 0.11^{\mathrm{a}}$ & $2.65 \pm 0.17^{\mathrm{a}}$ \\
Grapefruit peel + MD & $0.91 \pm 0.34^{\mathrm{a}, \mathrm{b}}$ & $3.38 \pm 0.42^{\mathrm{a}, \mathrm{c}}$ \\
Asparagus & $0.63 \pm 0.01^{\mathrm{b}}$ & $2.63 \pm 0.06^{\mathrm{a}}$ \\
Asparagus + MD & $0.85 \pm 0.03^{\mathrm{b}}$ & $2.73 \pm 0.08^{\mathrm{a}}$ \\
Artichoke & $0.78 \pm 0.08^{\mathrm{b}}$ & $3.30 \pm 0.09^{\mathrm{a}}$ \\
Artichoke + MD & $0.85 \pm 0.01^{\mathrm{b}}$ & $3.44 \pm 0.05^{\mathrm{a}, \mathrm{c}}$ \\
\hline
\end{tabular}

Ni: microbial population before spray drying (cfu/g).

Nf: microbial population after spray drying and beginning of the storage (cfu/g).

Ns: microbial population after 60 days of storage (cfu/g).

${ }^{\mathbf{a}, \mathbf{b}, \mathbf{c}, \mathbf{d}}$ Superscripts with different letters indicate statistical differences $(\mathrm{p}<0.05)$. 
The microbial reduction of microencapsulated $L$. casei using different vegetable extracts with or without MD after the spray drying process and after 60 days of storage at $25{ }^{\circ} \mathrm{C}$ are presented in Table 4 . Statistical analysis applying Tukey tests show significant difference $(\mathrm{p}<0.05)$ when using MD in combination with orange peel or grapefruit peel, obtaining a lower microbial reduction than without it, after the spray drying process. The lower microbial reduction after storage was presented with $L$. casei microencapsulated with asparagus, asparagus + MD and grapefruit peel.

\section{Discussion}

\subsection{Quality of L. casei Microencapsulated by Spray Drying}

The prepared suspensions of the vegetable extracts with maltodextrin (MD) adjusted to $25 \%$ affected the suspensions density and viscosity as well, in comparison with the suspensions of the vegetable extracts without $\mathrm{MD}$, because of the solid content difference. The solid content is an important property to consider for the spray drying process because it influences the humidity in the drying chamber and as a consequence, the process yield, based on the final mass of the powder obtained (Masters, 1985). In this study, the process yield was less than $30 \%$ when the vegetable extracts suspensions were used without $\mathrm{MD}$, and $50-60 \%$ when using $\mathrm{MD}$. An optimization of the process, considering the process yield, could be achieved with another suspension flux (Q) or inlet air temperature, but an overall outlet air temperature of $75^{\circ} \mathrm{C} \pm 5^{\circ} \mathrm{C}$ was searched to protect the probiotic thermal damage during the process, according to Ananta et al. (2005). Furthermore, the low solid content of the artichoke and asparagus extracts caused wet quenching during the drying process (excess of humidity in the drying chamber, with uncontrolled agglomeration) and no powder was obtained at the higher Q evaluated (15 $\mathrm{g} / \mathrm{min}$ ). Besides the low solid content, the vegetable extracts suspensions used for the spray drying process without MD produced powder losses due to stickiness problems on the wall chamber of the spray dryer which is also attributed to the chemical composition of the vegetable extracts, more specifically sugars, soluble fiber, pectins and organic acids, among others. Fruit juices, syrups and plant extracts have demonstrate stickiness problems during spray drying process and during storage as well, for their chemical components which are strongly related to their phase change during drying and crystallisation (Boonyai et al., 2004; Palzer, 2005; Langrish \& Chiou, 2008).

The final moisture content and water activity $\left(\mathrm{a}_{\mathrm{w}}\right)$ are also defined by the spray drying process (Huntington, 2004; Gianfrancesco et al., 2010) and are important parameters to maintain good quality of the powders obtained; Ananta et al. (2005) suggest moisture values lower than $5 \%$ and a range of 0.15 to 0.3 of $\mathrm{a}_{\mathrm{w}}$, to avoid agglomeration problems during transportation and storage. The moisture content and $\mathrm{a}_{\mathrm{w}}$ values of the powders obtained in this study, are within the suggested ranges. Nevertheless, the undesired agglomeration of powders is clearly appreciated with moisture gain kinetics of the powders, and with the adsorption isotherms of the powders, giving a complete revelation of the higroscopicity property of the powders. The adsorption isotherms of the microencapsulated $L$. case $i$ when using the vegetable extracts with MD present a significantly lower equilibrium moisture in a range of $a_{w}$ values of 0.6 to 0.9 . In this study it is demonstrated that the addition of MD decreases the moisture gain adsorption of the microencapsulated powders, which helps to maintain good quality of the microcapsules. Moreover, the moisture gain of the powders obtained from vegetable extracts without MD is up to 2 or 3 times more than when adding MD in the initial suspensions. The more hygroscopic powders were the ones formulated with orange peel extracts without MD. Langrish and Chiou (2008) studied the stability of spray dried hibiscus extracts adding citrus fiber extracts, obtaining better stability of moisture adsorption of the microencapsulated hibiscus when using citrus fibers, establishing that citrus fibers helps to form a more crystalline powder than without it. In this study, MD gave a better moisture stability to the powders than sole citrus extracts. The micrographs taken in this study also showed that a better coating surface was obtained when the vegetable extracts are mixed with $\mathrm{MD}$, the microcapsules are individually defined and no agglomeration between them is appreciated. The microcapsules obtained with the vegetable extracts presented a smooth surface and smaller individual particle size in comparison with the ones obtained when mixed with MD, but sinter bridges between particles are created, promoting an undesirable agglomeration which will eventually increase during storage.

\subsection{Survival Efficiency of L. casei Microencapsulated by Spray Drying}

The flux suspension (Q) did not show a significant difference in the moisture gain of the different powders, and since the powder yield was better with a $\mathrm{Q}$ of $10 \mathrm{~g} / \mathrm{min}$, the survival efficiency study was only conducted at this $Q$ value.

The efficiency of the microencapsulation of $L$. casei in this study was obtained calculating the microbial population reduction due to the spray drying process. Results demonstrate that the spray drying conditions 
caused a reduction in the microbial population among 0.63 and up to $1.25 \log$ cycles when using vegetable extracts for L. casei microencapsulation, being the citrus peels used alone, the ones which produced a higher microbial reduction. Boza, Barbin and Scamparini (2004) evaluated different carbohydrates for the encapsulation of Beijerinckia sp., including maltodextrin $10 \mathrm{DE}$, reporting a $0.18 \log$ microbial reductions after the spray drying process with an outlet air temperature of $75^{\circ} \mathrm{C}$, demonstrating that the cells did not suffered heat damage due to the process; since the drying condition evaluated in this study was $75^{\circ} \mathrm{C} \pm 5{ }^{\circ} \mathrm{C}$, it may be assumed that the process did not caused an important thermal damage to the probiotic cells.

According to Corcoran et al. (2004) the survival of the spray dried L. rhamnosus GG, with skim milk-based preparations, did not show an important change during storage when using an environmental temperature below $15^{\circ} \mathrm{C}$, but at $37^{\circ} \mathrm{C}$, the survival of the probiotic decreased linearly with the storage time, up to $5 \log$ cycles after 8 weeks of storage, while log reductions obtained in the present study are of 2.73 to 4.49 log cycles when using vegetable extracts with $\mathrm{MD}$ formulations for $L$. casei microencapsulation, stored at $25^{\circ} \mathrm{C}$.

It is important to attain a probiotic survival higher than $10^{6}-10^{7} \mathrm{cfu} / \mathrm{g}$ of product so that probiotics can exert their functions related to health benefits (Anal \& Singh, 2007; FAO/WHO, 2006). Even if the use of MD did not showed a significant positive effect on the $L$. casei spray drying process efficiency, based on the microbial reduction, after 60 days of storage, it was clear that the presence of MD protected better the probiotic, resulting in lower microbial reduction, particularly in comparison with the citrus extracts. Similar microbial reduction of the microencapsulated probiotic may be obtained if it is applied to solid food of low moisture content and water activity (cereal, granola bars and cookies, among others). Further studies are suggested to evaluate microbial reduction of microencapsulated probiotic applied to food with higher moisture content.

In conclusion, suspensions prepared with vegetable extracts in mixture with MD increases the microencapsulating process efficiency by spray drying, confers a better probiotic protection during storage and the hygroscopic properties are diminished. The proposed vegetable extracts suspensions prepared with maltodextrin for $L$. casei microencapsulation, may extend its applications for developing novel functional food.

\section{References}

Altieri, C., Bevilacqua, A., \& Sinigaglia, M. (2011). Prolonging the viability of Lactobacillus plantarum through the addition of prebiotics into the medium. Journal Food Science, 76(6), M336-345. http://dx.doi.org /10.1111/j.1750-3841.2011.02269.x

Amin, T., Thakur, M., \& Jain, S. C. (2013). Microencapsulation - the future of probiotic cultures. Journal of Microbiology, Biotechnology and Food Sciences, 3(1), 35-43.

Anal, A. K., \& Singh, H. (2007). Recent advances in microencapsulation of probiotics for industrial applications and targeted delivery. Trends in Food Science \& Technology, 18, 240-251. http://dx.doi.org/10.1016/j.tifs.2007.01.004

Ananta, E., Volkert, M., \& Knorr, D. (2005). Cellular injuries and storage stability of spray-dried Lactobacillus rhamnosus GG. International Dairy Journal, 15, 399-409. http://dx.doi.org/10.1016/j.idairyj.2004.08.004

AOAC. (2000). The Official Methods of Analysis. Washington, DC: Association of Official Analytical Chemists.

Baker, R. (1987). Controlled release of biologically active agents (pp. 206-214). New York: Wiley.http://dx.doi.org/10.1016/0168-3659(87)90012-5

Boonyai, P., Bhandari, B., \& Howes, T. (2004). Stickiness measurement techniques for food powders: a review. Powder Technology, 145, 34-46. http://dx.doi.org/10.1016/j.powtec.2004.04.039

Boza, Y., Barbin, D., \& Scamparini, A. R. P. (2004). Survival of Beijerinckia sp. microencapsulated in carbohydrates by spray-drying. Journal of Microencapsulation, 21(1), 15-24. http://informahealthcare.com/doi/pdf/10.1080/02652040310001599751

Chau, C. F., \& Huang, Y. L. (2003). Comparison of the chemical composition and physicochemical properties of different fibers prepared from the peel of Citrus sinensis L. Cv. Liucheng. Journal of Agriculture and Food Chemistry, 51, 2615-2618. http://dx.doi.org/10.1021/jf025919b

Corcoran, B. M., Ross, R. P., Fitzgerald, G. F., \& Stanton, C. (2004). Comparative survival of probiotic lactobacilli spray-dried in the presence of prebiotic substances. Journal of Applied Microbiology, 96, 1024-1039. http://dx.doi.org/10.1111/j.1365-2672.2004.02219.x

Desmond, C., Stanton, C., Fitzgerald, G. F., Collins, K., \& Ross, R. P. (2001). Environmental adaptation of probiotic lactobacilli towards improvement of performance during spray drying. International Dairy 
Journal, 11, 801-808. http://dx.doi.org/10.1016/S0958-6946(01)00121-2

FAO/WHO. (2006). Probiotics in food. Health and nutritional properties and guidelines for evaluation. FAO Food and Nutrition Paper No. 85. World Health Organization and Food and Agriculture Organization of the United Nations, Rome.

Fuchs, M., Turchiuli, C., Bohin, M., Cuvelier, M. E., Ordonnaud, C., Peyrat-Maillard, M. N., \& Dumoulin, E. (2006). Encapsulation of oil in powder using spray drying and fluidised bed agglomeration. Journal of Food Engineering, 75, 27-35. http://dx.doi.org/10.1016/j.jfoodeng.2005.03.047

Gardiner, G. E., O’Sullivan, E., Kelly, J., Auty, M. A. E., Fitzgerald, G. F., Collins, J. K., \& Stanton, C. (2000). Comparative survival rates of human-derived probiotic Lactobacillus paracasei and L. salivarius strains during heat treatment and spray drying. Applied and Environmental Microbiology, 66, 2605-26. http://dx.doi.org/10.1128/AEM.66.6.2605-2612.2000

Gianfrancesco, A., Turchiuli, C., Flick, D., \& Dumoulin, E. (2010). CDF modeling and simulation of maltodextrin solutions spray drying to control stickiness. Food Bioprocess Technology, 3, 946-955. http://dx.doi.org/10.1007/s11947-010-0352-2

Gibson, G. R., Probert, H. M., Loo, J. V., Rastall, R. A., \& Roberfroid, M. B. (2004). Dietary modulation of the human colonic microbiota: updating the concept of prebiotics. Nutrition Research Review, 17, 259-275. http://dx.doi.org/10.1079/NRR200479

Huntington, D. H. (2004). The influence of the spray drying process on product properties. Drying Technology, 22(6), 1261-1287. http://dx.doi.org/10.1081/DRT-120038730

Langrish, T., \& Chiou, D. (2008). Stabilization of moisture sorption in spray-dried bioactive compounds by using novel fibre carriers to crystallize the powders. International Journal of Food Engineering, 4(1), 1-7. http://dx.doi.org/10.2202/1556-3758.1359

Masters, K. (1985). Spray drying. New York: Longman Scientific and Technical, Wiley.

Murugesan, R., \& Orsat, V. (2012). Spray drying for the production of nutraceutical ingredients - a review. Food Bioprocess Technology, 5, 3-14. http://dx.doi.org/10.1007/s11947-011-0638-z

Nazzaro, F., Orlando, P., Fratianni, F., \& Coppola, R. (2012). Microencapsulation in food science and

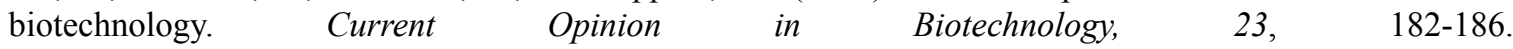
http://dx.doi.org/10.1016/j.copbio.2011.10.001

Palou, E., López-Malo, A., \& Argaiz, A. (1997). Effect of temperature on the moisture sorption isotherms of some cookies and corn snacks. Journal of Food Engineering, 3(1), 85-93. http://dx.doi.org/10.1016/S0260-8774(96)00019-2

Palzer, S. (2005). The effect of glass transition on the desired and undesired agglomeration of amorphous food powders. Chemical Engineering Science, 60, 3959-3968.http://dx.doi.org/10.1016/j.ces.2005.02.015

Rokka, S., \& Rantamäki, P. (2010). Protecting probiotic bacteria by microencapsulation: challenges for industrial applications. European Food Research Technology, 231, 1-12. http://dx.doi.org/10.1007/s00217-010-1246-2

Tan, L. W., Ibrahim, M. N., Kamil, R., \& Taip, F. S. (2011). Empirical modeling for spray-drying process of sticky and non-sticky products. Procedia Food Science, 1, 690-697. http://dx.doi.org/10.1016/j.profoo.2011.09.104

Werner, S. R. L., Jones J. R., Paterson, A. H. J., Archer, R. H., \& Pearce, D. L. (2007). Air-suspension particle coating in the food industry: Part I - state of the art. Powder Technology, 171, 25-33. http://dx.doi.org/10.1016/j.powtec.2006.08.014

\section{Copyrights}

Copyright for this article is retained by the author(s), with first publication rights granted to the journal.

This is an open-access article distributed under the terms and conditions of the Creative Commons Attribution license (http://creativecommons.org/licenses/by/3.0/). 